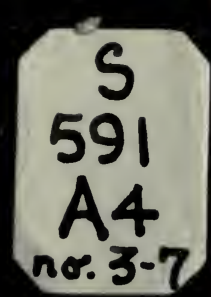

UC-NRLF
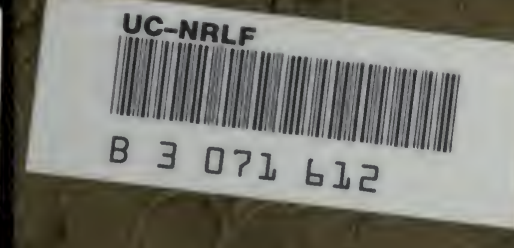

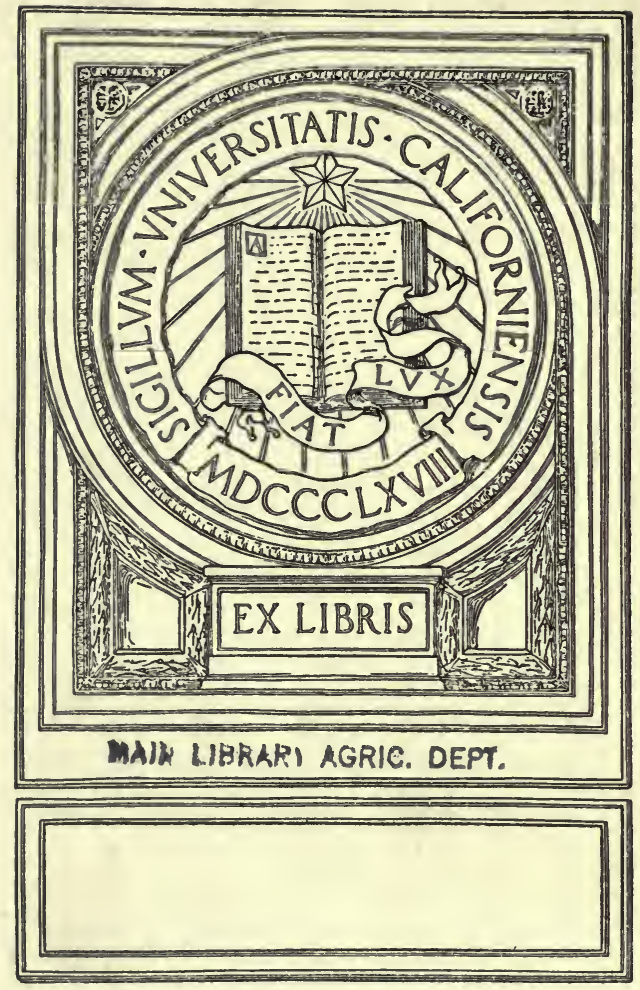
Digitized by the Internet Archive in 2007 with funding from Microsoft Corporation 
MAIR IIBKAWI AGRIC. DEPI 
cincunar N No.3.

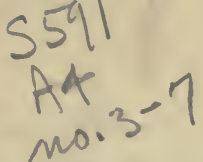

United States Department of Agriculture,

DIVISION OF SOILS.

\section{THE SOILS OF THE PECOS VALLEY, NEW MEXICO.}

In March, 1899, a party was sent by the Secretary of Agriculture, under the direction of the Chief of the Division of Soils, to map the soils of the irrigated districts of the Pecos Valley, New Mexico, with particular reference to the extent of and damage from "alkali" and seepage waters, and to investigate methods for the prevention of further damage and for the reclamation of lands already abandoned from these causes. Three months were spent in a thorough and detailed examination of the Carlsbad and Roswell areas, with a reconnoissance around Hagerman, N. Mex., and Barstow, Tex. The following brief review of the results of this work is presented, pending the completion of a more detailed report:

THE CLIMATE.

The climate of New Mexico is distinctly arid. The average yearly rainfall at Carlsbad is, according to a four years' record, 12 inches, with a larger proportion of rain falling during the summer and fall, from May to October, inclusive. There are occasional heavy local rains during the summer, which cause great floods in the Pecos; these floods generally commence in May while crops are yet tender, and it is upon them that the large storage reservoirs at Carlsbad are mainly dependent for the supply to the irrigation lands of that district.

The normal evaporation is said to be about 10 feet at Carlsbad from a water surface, and, as the reservoirs when full average only about 20 feet deep, it will be seen that this evaporation is an important factor both in the matter of the available water supply and its condition when long stored in the reservoir, owing to the increased salt content due to the concentration through evaporation. During the spring of 1899 the regular spring floods did not come down, the first reaching the reservoir late in June. Previous to this the evaporation in the reservoir exceeded the inflow from the Pecos River, and the condition of the water was perhaps at its worst.

\section{THE DRAINAGE AREA.}

The Pecos River drains nearly all of the southeastern third of New Mexico. Rising in the Santa Fe Range, the stream flows through the inclined rocks of the mountains as a typical mountain 
stream until the horizontal strata of the plains are reached. Its main tributaries all come from the western side, and they too are mountain streams rising in the White, Sacramento, and Guadalupe mountains. In time of floods these streams run large quantities of water throughout their courses, but during the greater part of the year they disappear, being absorbed in the sands and gravels of their beds soon after leaving the mountains. The numerous springs all along the west bank of the Pecos indicate that much of this water appears again as seepage water after a long journey under ground.

\section{THE IRRIGATION SYSTEMS OF THE PECOS.}

There are four large systems of irrigation on the Pecos River in New Mexico and Texas:

1. The Roswell area, deriving water from the North and South Spring rivers and the Berendo Springs.

2. The Hagerman area or Northern Canal System, the water for which is obtained from the unused, waste, and drainage waters from the Roswell area, and in time of flood from the Hondo River.

3. The Carlsbad area or Southern Canal System obtains water directly from the Pecos River by storage in two large reservoirs.

4. The Barstow area also receives water from the Pecos, but without storage.

\section{ROSWELL AREA.}

The Roswell area is confined to the land immediately around the junction of the Hondo and Pecos rivers, with narrow strips along the Berendos. The waters of the North and South springs come from great depths in the Hondo flood plain, and no doubt are a part of the water lost through seepage from the upper part of the rivers and tributaries just after they leave the mountains. The water contains on an average 75 parts of soluble matter per 100,000. Of this, only 35 parts are likely to remain in solution and accumulate within the soil, to the detriment of plant growth. The remaining 40 parts crystallize out on evaporation and concentration of the water, and are not readily soluble thereafter. The waters of the Berendo Springs, which come from the great gypsum plains, extending to the north along the Pecos, are not so good, as they contain 250 parts of soluble mattêr per 100,000 , of which about one-half is likely to accumulate in solution upon evaporation of the water. The lands to which Berendo water is applied all lie close to the stream banks and have good underdrainage, so that no damage has resulted from the use of this saline water. There is no black alkali or sodium carbonate in the Pecos Valley, so far as observed. 
THE SOILS OF THE ROSWELL AREA.

The soils of the Roswell area may be classed under three types:

1. Pecos loam, upland prairie-like soils.

2. Roswell loams, lower lands not bottoms.

3. Meadows or bottom lands.

(1) The Pecos loam is a light, sandy soil found on the upper benches away from the streams. It has been cultivated very little, except during flood in the Hondo, and has never shown trouble from alkali.

(2) The Roswell loams cover by far the greater part of the irrigation district of Roswell. They differ from the Pecos loam in being heavier; that is, they contain a higher percentage of fine material. They are subdivided into sandy loam and loam. A bed of clay underlies both soils, but that under the loam is much nearer the surface than that under the sandy loam. This clay is very impervious to water. When irrigation water is freely applied, the excess seeps down until this stratum of clay is reached, when it accumulates and rises, gradually filling the subsoil until the soil itself becomes too wet with seepage water for crops. Evaporation takes place from the wet surface, and as the soil moisture concentrates through evaporation the soluble salts accumulate at or near the surface of the ground until finally plants can no longer grow. Of the kind of alkali found at Roswell, about one-half of 1 per cent in the top foot of soil is sufficient to prevent alfalfa growing. Drainage is the one great need of these soils. The water drawn off from the subsoil would lessen the evaporation from the surface and carry out into the rivers the salt which has accumulated near the surface, besides lowering the level of the ground water.

(3) Meadows or bottom lands occur along the North and South Spring rivers and along the Hondo. The soil in all of these is formed from mud, deposited by the Hondo when in flood, mixed with the remains of tule swamps and other water-loving vegetation. Most of the bottom lands are wet and would require drainage even in a humid climate, but situated as they are, quantities of alkali are accumulating in the surface, and only by thorough drainage and washing away of these salts can these lands now be reclaimed.

THE PROBLEMS OF THE ROSWELL DISTRICT.

To the most casual observer, the flat tract of land to the southeast of Roswell lacks underdrainage. The water table lies at an average depth of less than 5 feet below the surface. Over much of what was once the best land in the district water can now be found within 3 feet of the surface during part of the year. Such a condition of standing water is unhealthy to the plants growing on the surface and, moreover, in a country where the subsoil is charged with alkali 
salts it is dangerous to allow this subsoil water to collect and evaporate from the surface. The best results from cultivation can never be realized until the land is thoroughly drained. Cultivation and forage crops which shade the ground will to a large extent, prevent evaporation, but in many cases the damage has gone too far for such preventive measures to be successfully used.

THE HAGERMAN AREA OR THE NORTHERN CANAL SYSTEM.

This area comprises a narrow strip of land running south from the Roswell area along the Pecos River. The water of the Northern Canal is a mixture of the Berendos and Spring rivers, together with the waste, drainage, and seepage water from the Roswell district. The character of the Northern Canal water is therefore not the best. It carries on an average about 200 parts of soluble matter per 100,000 , of which about 115 parts are resoluble after evaporation and therefore likely to accumulate in solution. Thus we see that the water introduced into the soil contains one-tenth of 1 per cent of soluble matter. Since few plants can successfully grow with their roots in contact with a solution of more than 1 per cent concentration, it requires only a concentration to one-tenth to bring the soil moisture to the maximum limit allowable. Proper precautions must be taken, therefore, to avoid excessive evaporation from the surface of the soil.

The soils at Hagerman are of corresponding types to the Roswell area, with the addition of one new type-gypsum soil, or "yeso" as it is termed by the native Mexicans. The soil is so much more typically developed in the Carlsbad area that its description will be given there.

The main problem which confronts the farmer at Hagerman is similar to that in the Roswell area-that is, the prevention of the accumulation of alkali near the surface. Over land which has adequate natural drainage very little damage has been felt from this cause. On the heavier soils and where the gypsum comes close to the surface, these lands must be underdrained. One attempt has been made to underdrain the land and this with fair success, though not as yet completed.

THE CARLSBAD AREA OR SOUTHERN CANAL SYSTEM.

The flow of the Pecos above Carlsbad sometimes becomes very small, as low as 50 to 75 cubic feet per second. At other seasons of the year great quantities of water flow. Two large storage reservoirs have been constructed on the Pecos to hold back this flood water, and from these reservoirs the water is turned into the Southern Canal as desired. The canal was originally planued as far south as the Delaware River, but has only been used to a short distance below the Black River. The average condition of this water is not 
good, as it contains about 300 parts of soluble matter per 100,000 , of which over half are harmful salts - the condition of the water varying from 200 parts per 100,000 to 500 parts per 100,000 . With 500 parts per 100,000 , or one-half of 1 per cent, the solution contains onefourth of 1 per cent of harmful salts; 1 per cent being the limit of endurance of crops. There is considerable salt already in the soil, therefore, but little evaporation is required at such time to concentrate the soil moisture beyond the limit of endurance. Furthermore, with the conditions so near this limit, vegetation is not as healthy or as thrifty as could be desired and crops are subject to disease. During the winter the water is constantly evaporating from the reservoirs, and if the inflow is small it may be concentrating. This water, in its worst condition, is applied to the young and tender plants just at the time when the water should be best. The first summer floods bring down large quantities of alkali which have accumulated on the surface of the ground of the Upper Pecos, and these floods seldom improve the water. In later floods the water is better and reaches its best condition.

THE SOILS OF THE CARLSBAD AREA.

The soils of the Carlsbad (formerly Eddy) area have been divided into four types:

1. Sand-dune soils.

2. Pecos loams.

3. Pecos conglomerate soils.

4. Gypsum soils.

(1) Along the banks of the river, filling up the tortuous bends of its course, are found large areas of sand soils drifting with the winds as dunes. These sands are composed of a very uniform grade of clean grains, rounded by attrition. When cultivated, these soils drain easily, owing to their favorable situation near the banks of the river. Quantities of salt are to be found in these soils before irrigation, though little damage has been done by this alkali, due to the ready leaching by the irrigation water.

(2) Pecos loams cover by far the largest and most important part of the Carlsbad district. They are identical in texture and physical properties with the loams described as forming the uplands at Roswell. They are formed, much in the same way as the Pecos loams at Roswell, from the sediments of an ancient lake. This loam contains a large proportion (10 to 20 per cent) of carbonate of lime, and from 1 to 2 per cent of sulphate of lime or gypsum. No accumulation of alkali was found within this area, though borings were made to a depth of 20 feet, except in the draws, where the seepage from the surrounding country, together with evaporation, have accumulated large quantities of alkali in concentrated solution. There are 
two points in particular where the irrigation or leakage from canals on the upland has swamped low-lying lands-along the foot of the gravel bluff which bounds the Pecos bottoms southeast of Carlsbad, and in another draw immediately east of Otis. In both of these cases, which are rapidly being brought into the condition of alkali flats, the water has seeped out of the surrounding higher lands and swamped the draw. Evaporation has, in the course of several years, covered part of these areas with a crust of salt. Attempts are now being made to reclaim a portion of one of these flats by open drains. Owing to the soft ground, open drains are a constant source of trouble and expense. Tile drains will be found much better, though the initial cost may be higher.

(3) The Pecos conglomerate soils are formed from the weathering of the local beds of conglomerate or, in some cases, of the unconsolidated gravel. All of these soils are classed as gravelly, and at present are not used.

(4) The gypsum loam soil occupies a large irregular area between Cass draw and Black River, with another large area south of Black River and Malaga. The pure gypsum is generally covered with a thin layer of loam, varying from a fraction of an inch to 3 feet. The gypsum, when dry, is hard and compact, but when wet it absorbs water as readily as a loaf of sugar, and breaks down into a soft mass which is very pervious to water and possesses great capillary powers. The height and rapidity with which water rises in gypsum soils is very remarkable when compared with others. In a field wet spots were noticed where, on boring, no standing water was found within 6 feet of the surface. The great capillary power keeps the surface perceptibly moist all the time, and, when placed under the hot sun of southern New Mexico, it can be seen that the evaporation will soon concentrate the soil solutions to such a degree that few plants may live. It is undoubtedly this physical property, and not the chemical nature of the gypsum itself, which renders its cultivation so unprofitable, though there are some plants to which the presence of so much lime is obnoxious.

Drainage can be recommended for gypsum soils, but since the capillary powers are so great and the evaporation from the soil surface so rapid it is a question whether reclamation of these gypsum lands by costly drainage is a profitable or safe investment at present. There are so many serious difficulties in the way of practical cultivation of gypsum lands that from our present knowledge this attempted reclamation is to be discouraged.

THE PROBLEMS OF THE CARLSBAD AREA.

With the exception of the sand dune soils bordering immediately on the Pecos River, wet at times of high water, and in a few cases 
the gypsum also, the soils of the Carlsbad area were originally free from noticeable quantities of alkali. The sources of the present accumulations of alkali are all directly traceable to the irrigation water. All recommendations for the prevention of damage by alkali must, therefore, point primarily to a change in the method of handling the present supply of water or of obtaining a better supply.

\section{DRAINAGE,}

Drainage is recommended as of most general application in the Carlsbad district. Tile drains should be laid for soils in which the water table rises above 3 feet. When the soil is open and dry, and where seepage water has not accumulated, cultivation or growth of alfalfa should be used to prevent surface evaporation and the consequent concentration of the soil moisture. Salt determinations have been made in cultivated and uncultivated ground, side by side, in which the uncultivated land showed three times as much alkali as the cultivated. Where salt has already accumulated, drains must be laid and the salt washed out by flooding. Surface washing without drainage is of little avail, for the first film of water dissolves the salt and sinks into the ground to appear again when evaporation commences. If, however, this water can pass through the soil and into drains, the salt is carried away, and no further damage from it need be feared.

THE BARSTOW AREA.

The Barstow area lies in an old lake basin, and the soils are derived from the old lake sediments. The soils all contain alkali in their lower depths, and in many cases are underlaid by gypsum.

The Pecos water, where taken out, contained in June, 1899, about 390 parts of soluble matter per 100,000, while the Pecos opposite Pecos City contained 525 parts. This concentration of the water, which must be near its average condition, is so near the limit for plant growth that only where the most favorable conditions of soil and drainage are found can agriculture be termed successful.

Thos. H. Means,

Frank D. Gardner,

Approved: Assistants.

JAMES WILsON, Secretary of Agriculture. 

YC $6789:$ 
